\title{
The water exchange and water quality improvement measures on the example of the Gulf of Cheboksary
}

\author{
Sergey Pavlov ${ }^{1}$, Maria Arlanova ${ }^{1}$, Aleksandr Nikonorov ${ }^{1}$, Vitaly Terleev ${ }^{1}$, Issa Togo ${ }^{1}$, \\ Yulia Volkova ${ }^{1}$, Vitaly Garmanov ${ }^{2}$, Dmitry Shishov ${ }^{2}$, Kasim Layshev $^{3}$ and \\ Mikhail Arkhipov ${ }^{3}$ \\ ${ }^{1}$ Peter the Great St.Petersburg Polytechnic University, Polytechnicheskaya, 29, St. Petersburg, \\ 195251, Russia \\ ${ }^{2}$ St.Petersburg State Agrarian University, Peterburgskoye shosse, 2, St. Petersburg-Pushkin, \\ 196601, Russia \\ ${ }^{3}$ Federal State Budgetary Institution "North-West Centre of Interdisciplinary Researches of Problems \\ of Food Maintenance", Podbelskogo shosse, 7, St. Petersburg-Pushkin, 196608, Russia
}

\begin{abstract}
This paper is dedicated to the Gulf of Cheboksary. The gulf has an important recreational and decorative function. It has been an integral part of the urban landscape for several decades. There is an eutrophication process, accompanied by the development of blue-green algae and the appearance of an odour in early spring, despite the water quality improvement measures. Measures that will improve the water exchange in the Gulf are proposed in this paper. Problems with the sanitary condition of the water body can occur without taking these measures. Therefore, the theme of this research is quite urgent.
\end{abstract}

\section{Introduction}

The Gulf of Cheboksary is one of the main water objects of the Chuvashia capital. The object was built from the beginning of the 1980s to 1996 [1]. In fact, the Gulf is a part of the Cheboksary reservoir and consists of the three basins, formed by the dams, which part off the floodplain of the Volga River tributary - the River Cheboksarka (Fig. 1-3). There are many reservoirs with minor fluctuations in water level, similar to Cheboksary reservoir. It is possible to use some of these reservoirs to create basins, similar to the considered object, which could improve the landscape of the settlement $[2,3]$.

A retention pound for heavily polluted river water located in the upstream, from which the flow goes through the pipes and discharges into the Volga River after the conditioning at municipal wastewater treatment plants. The reservoir called I-line Gulf is located further. The II-line Gulf is adjacent to the Volga River. Retention pound is separated from the I-line Gulf by the bulk earth dam with the walkway on the berm (surface mark of the water level of retention pound is lower than I-line Gulf water level). The I-line Gulf (normal water level $=69 \mathrm{~m}$ ) backwater is created by a concrete dam. There is a pedestrian bridge at the top of the dam. The water surface level at the II-line Gulf is equal to $68 \mathrm{~m}$, the average depth $-3 \mathrm{~m}$ [4-6]. 


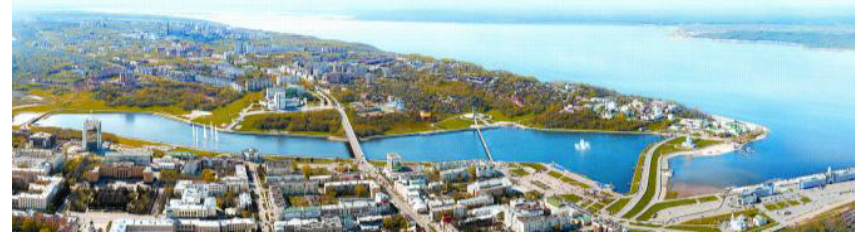

Fig. 1. The Gulf of Cheboksary - air photography.

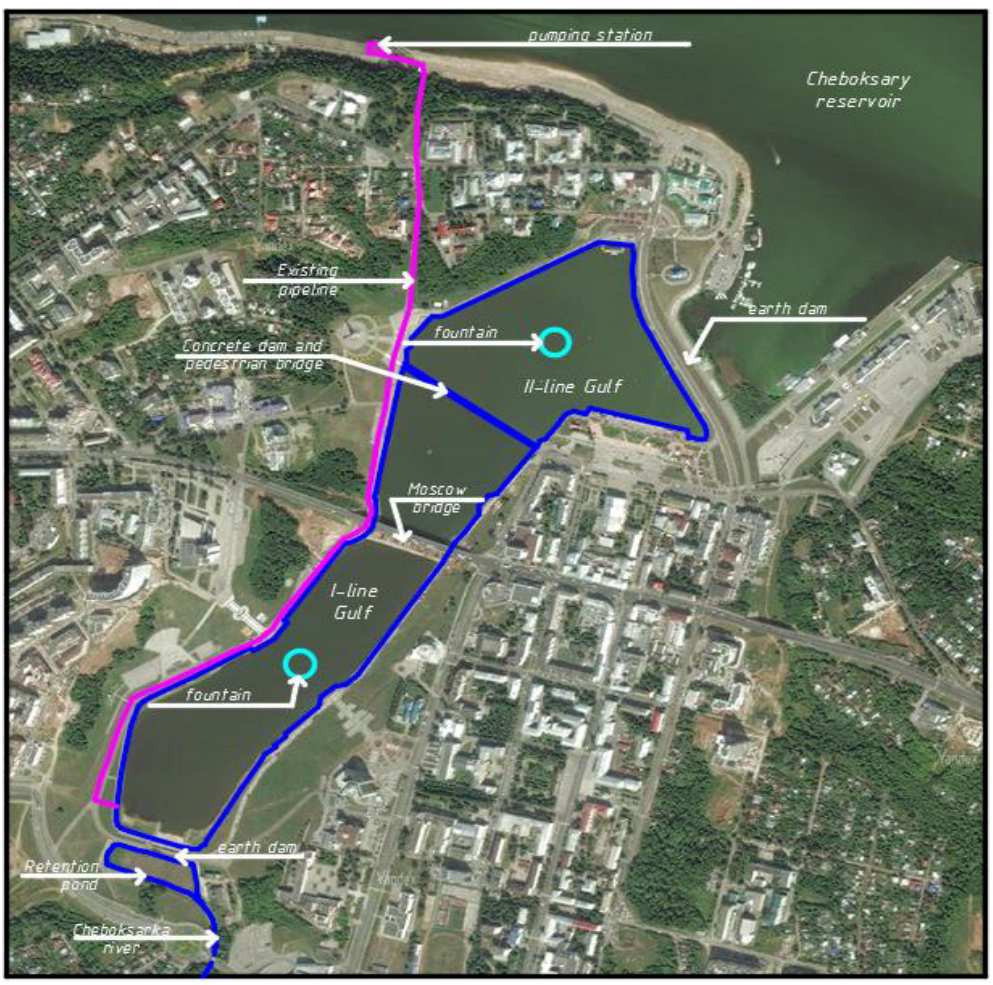

Fig. 2. The Gulf of Cheboksary and its hydraulic systems. Green color - earth dams, violet penstock, blue - coasts.

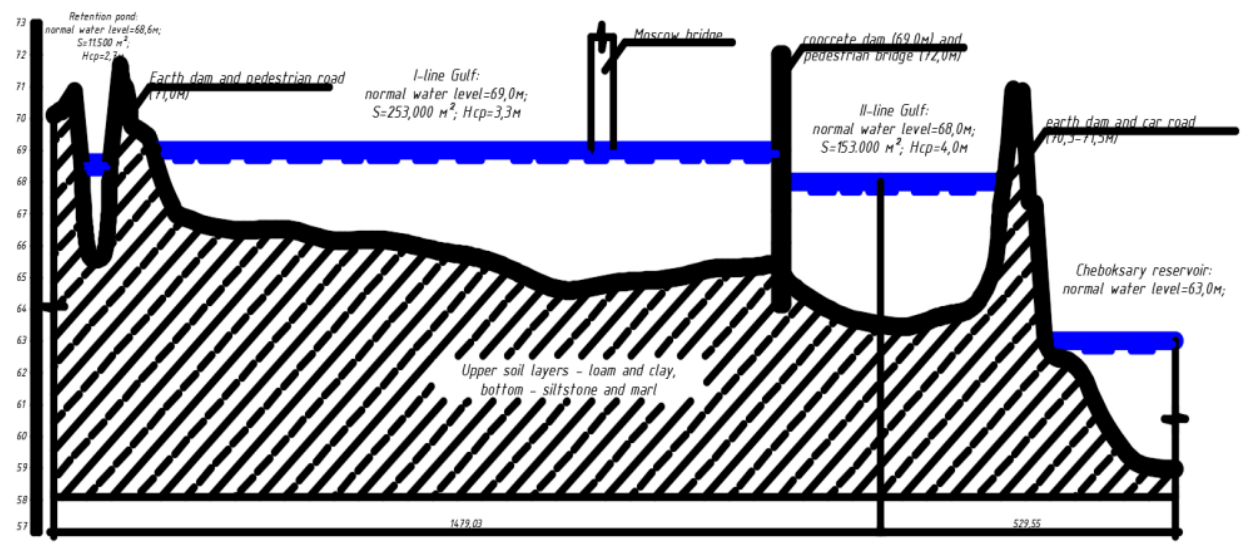

Fig. 3. The Gulf of Cheboksary surface curve. 
The main entrance is located in the submerged left corner of the building; the porch is decorated with the canopy, which serves as a basis for the balcony-loggia on the second floor. The fence, which traditionally includes gate and wicket, links to the left side of the building and connects it with the wing [7].

In the winter season (November-March) the water discharge of the I-line Gulf water is made through the gates located in the body of spillway dam under the pedestrian bridge. The project does not provide a complete emptying of the I-line Gulf. The water residue level when the gates are fully open is equal to $0,3 \mathrm{~m}$ at the gate and $2 \mathrm{~m}$ in the deepest place (under the Moscow bridge) [8-12].

The current water exchange system includes a pump station, which takes water from Cheboksary reservoir, $1000 \mathrm{~mm}$ diameter pipe, connecting the pumping station with the beginning of the I-line Gulf, and inlet structures. Large amounts of water filling, mostly adjacent to the banks are not affected by the flow, due to the concentration of the stream in one point.

The standing and slowly flowing water in shallow areas is well warmed by the sun, which contributes to the development of blue-green algae. This process of "bloom" is completely unacceptable for the pond in the center of the city, which is actively used for recreation. The process of eutrophication of the Gulf of Cheboksary made it impossible to create beaches on its banks [12-15].

\section{Materials and methods}

\subsection{Proposed solution for the Gulf of Cheboksary sanitary condition improvement}

It is necessary to change the water volume of city recreational ponds at least four times per year, according to the existing regulations and recommendations. The value of the supplied water volume is not mentioned in the published references.

Therefore, $17,250,000 \mathrm{~m}^{3}$ of water is fed into the upper part of the gulf during the season. The volume of the I-line and II-line Gulf is equal to $1,150,000 \mathrm{~m}^{3}$. Consequently, the volume of water supply exceeds the standard by almost four times. However, there are dead zones with eutrophication, despite the significant amount of supplied water.

The authors suggest, that the water saving and sanitary condition improvement of the Gulf of Cheboksary could be achieved by the implementation of developed system of measures. These measures allow distributing water from the pumping station across all of the water area of the gulf [16-20].

The first phase of the measures development supposes the creation of the water distribution scheme of the I-line Gulf. This paper proposes to supply the water with the help of pipe system, using the existing pumping station and pipeline (Fig. 4). 


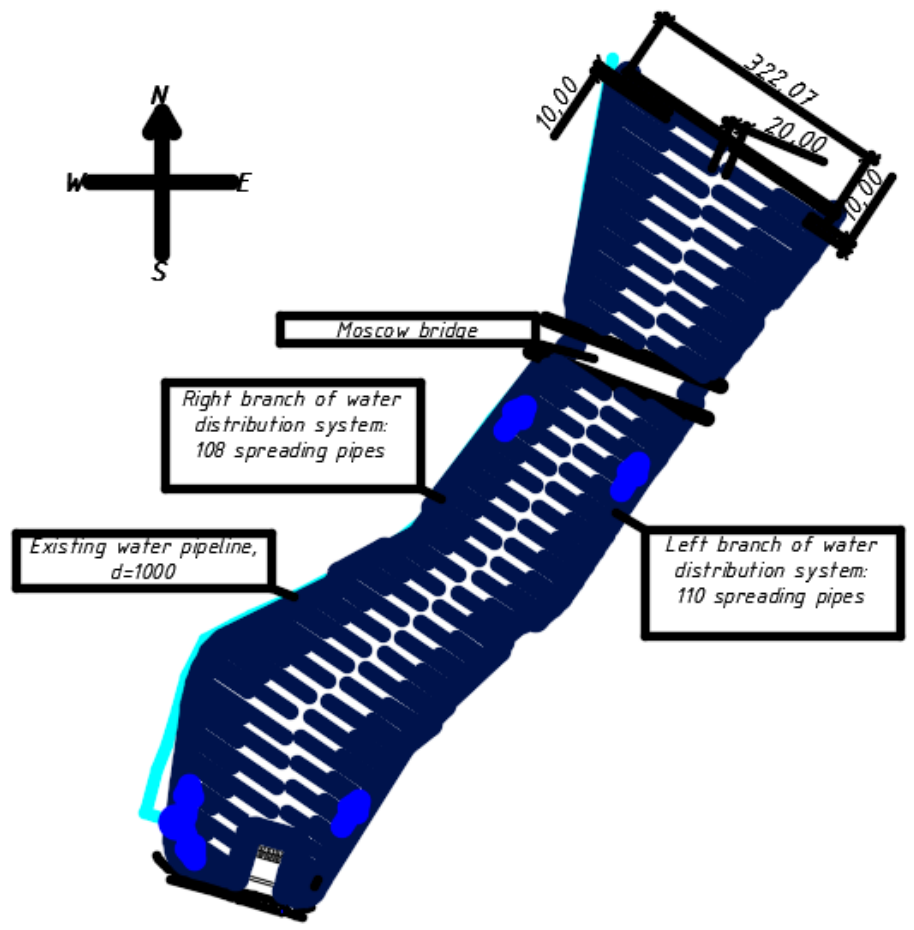

Fig. 4. Water distribution system of the I-line Gulf (short pipes are not shown).

Two trunk pipes are suggested to be joined to the existing pipeline, in the point of its outlet in the upper part of I-line Gulf. These trunk pipes go respectively along the right and left banks to the concrete dam, which divides the I-line and II-line Gulf. The pipes, which are directly supplying water to the Gulf, are attached to those trunk pipes. Step $-10 \mathrm{~m}$ was accepted in the first approximation in accordance with the recommendations, it could be refined further [21]. Heads of pipes are located in the «checkerboard» order: heads of short pipes are spaced from the shoreline at $1 \mathrm{~m}$; medium pipes - quarter length of the Gulf; long pipes (going after medium, before the short) - half length of the Gulf. This arrangement of heads allows covering the entire area by the release of water [22-24].

\subsection{Hydraulic calculation of the proposed water distribution system elements}

The tasks of conducted calculation were:

- The definition of pipelines diameters, providing the steady water supplying to all points of the overflow;

- Proposals for pumping equipment, providing the required flow and pressure.

The initial calculation parameter is flow, required to provide the regulatory water cycle. As stated above, regulations and recommendations propose the fourfold change of water volume per year. The discharge from the Gulf of Cheboksary into the Cheboksary reservoir usually takes place at the end of November, filling occurs in April. Thus, it is possible to take the length of full filled Gulf as 200 days. Assuming that the volume of I-line Gulf is $740,000 \mathrm{~m}^{3}$, it should be supplied by $14,800 \mathrm{~m}^{3}$ of water per day. 
Water distribution system pipelines are calculated as long pipelines. Their diameter in further calculations is indicated as $D$ with narrow indexes, absolute roughness is indicated by $\Delta$ (assumed equal to $0,1-0,15 \mathrm{~mm}$ ). Calculation of long pipelines is carried out by the simplified scheme, according to the following assumptions:

- The main application area of these calculations - water networks, with average flow velocity;

- $\quad$ The flow rate in the pipe $Q$ is the main characteristic of the water network;

- Hydraulic gradient is more convenient characteristic of the long pipeline.

Is seems optimal to produce calculation by the dead-end water supply scheme for these problem (the shortest by length non-closed pipeline system). Calculation of this scheme begins with the choice of the trunk pipeline. This pipeline must be the longest, have the highest flows and supply the water to the most remote points.

Bitumen steel pipes will be used for the water network system. Reference materials with the flow modulus $K$ and hydraulic friction coefficient $\lambda$ will be used for the calculation. The final selection of the pipes $D_{o k}$ will be made according to values of calculated diameter.

\section{Results and discussions}

\subsection{Heating system - design, elements and technical condition}

The calculation is made for the system that works 200 days (April-November). The results of the calculations performed by the authors calculation system in Excel program, are presented in the Tables 1-2, where: $Q_{\text {pipe.over }}, D_{\text {over.calc }}, D_{\text {over.ok }}$ - values of pipe flows, design and final pipe diameter for main branches of water supply.

Table 1. Hydraulic calculation of the right branch of water distribution system, I-line Gulf

\begin{tabular}{|c|c|c|c|c|c|c|c|c|c|c|}
\hline $\begin{array}{c}\text { Number } \\
\text { of } \\
\text { pipe }\end{array}$ & $\begin{array}{c}v_{e}, \\
\mathrm{~m} / \mathrm{s}\end{array}$ & $\begin{array}{c}D_{\text {prelim }}, \\
\mathrm{mm}\end{array}$ & $K_{\text {prelim }}$ & $\begin{array}{c}Q_{\text {tr }}, \\
\mathrm{m} / \mathrm{s}\end{array}$ & $\begin{array}{c}D_{\text {calc }}, \\
\mathrm{mm}\end{array}$ & $\begin{array}{c}D_{\text {ok }}, \\
\mathrm{mm}\end{array}$ & $\begin{array}{c}\text { Number } \\
\text { of } \\
\text { area }\end{array}$ & $\begin{array}{c}Q_{\text {pipe.over, }} \\
\mathrm{m} / \mathrm{s}\end{array}$ & $\begin{array}{c}D_{\text {over.calc }}, \\
\mathrm{mm}\end{array}$ & $\begin{array}{c}D_{\text {over.ok, }}, \\
\mathrm{mm}\end{array}$ \\
\hline 1 & 2,0 & 50 & 0,012 & 0,002 & 33,9 & 50 & - & 0,002 & 33,9 & 50 \\
\hline 2 & 2,0 & 50 & 0,012 & 0,002 & 33,9 & 50 & $1-2$ & 0,004 & 48,0 & 50 \\
\hline 107 & 2,0 & 50 & 0,012 & 0,002 & 33,9 & 50 & $106-107$ & 0,193 & 350,7 & 400 \\
\hline 108 & 2,0 & 50 & 0,012 & 0,002 & 33,9 & 50 & $107-108$ & 0,195 & 352,4 & 400 \\
\hline
\end{tabular}

As a result, the flow to the right branch with the 108 water supply pipes will be equal to $Q_{r . b r}=0,195 \mathrm{~m}^{3} / \mathrm{s}$, the flow on the left branch $-Q_{l . b r}=0,199 \mathrm{~m}^{3} / \mathrm{s}$. The entire system requires $Q_{\text {sys }}=0,394 \mathrm{~m}^{3} / \mathrm{s}$.

Table 2. Hydraulic calculation of the left branch of water distribution system, I-line Gulf

\begin{tabular}{|c|c|c|c|c|c|c|c|c|c|c|}
\hline $\begin{array}{c}\text { Numbe } \\
\text { of } \\
\text { pipe }\end{array}$ & $\begin{array}{c}v_{e}, \\
\mathrm{~m} / \mathrm{s}\end{array}$ & $\begin{array}{c}D_{\text {prelim }}, \\
\mathrm{mm}\end{array}$ & $K_{\text {prelim }}$ & $\begin{array}{c}Q_{\text {tr }}, \\
\mathrm{m}^{3} / \mathrm{s}\end{array}$ & $\begin{array}{c}D_{\text {calc }}, \\
\mathrm{mm}\end{array}$ & $\begin{array}{c}D_{\text {ok }}, \\
\mathrm{mm}\end{array}$ & $\begin{array}{c}\text { Number } \\
\text { of } \\
\text { area }\end{array}$ & $\begin{array}{c}Q_{\text {pipe.over },} \\
\mathrm{m}^{3} / \mathrm{s}\end{array}$ & $\begin{array}{c}D_{\text {over.calc }}, \\
\mathrm{mm}\end{array}$ & $\begin{array}{c}D_{\text {over.ok }}, \\
\mathrm{mm}\end{array}$ \\
\hline 1 & 2,0 & 50 & 0,012 & 0,002 & 33,9 & 50 & - & 0,002 & 33,9 & 50 \\
\hline 2 & 2,0 & 50 & 0,012 & 0,002 & 33,9 & 50 & $1-2$ & 0,004 & 48,0 & 50 \\
\hline$\vdots$ & & & & & & & & & & \\
\hline 109 & 2,0 & 50 & 0,012 & 0,002 & 33,9 & 50 & $108-109$ & 0,197 & 354,0 & 400 \\
\hline 110 & 2,0 & 50 & 0,012 & 0,002 & 33,9 & 50 & $109-110$ & 0,199 & 355,6 & 400 \\
\hline
\end{tabular}


Number of system working hours per day for four-time water exchange for period 200 days $n_{k}$, with the received flow is equal to:

$$
n_{h}=v_{e} \cdot k_{W}\left(n_{d} \cdot Q_{s y s} \cdot 3600\right) \text {, hour, }
$$

where: $k_{W}=4$ - water exchange coefficient; $n_{d}=200$ - number of working days of the system for summer period (April-November), days.

$$
n_{h}=740000 \cdot 4 /(200 \cdot 3600 \cdot 0.394)=10,43 \text { hours. }
$$

Total 10 hours and 26 minutes per day is sufficient to exchange all the water in I-line Gulf four times per season over 200 days.

\subsection{Pump selection}

It is necessary to determine the calculated flow and pressure of the pump for selection of the pump that supplies the water to the distribution system. Authors propose to take four working pumps without the reserve. Flow of the one pump will be about $0,1 \mathrm{~m}^{3} / \mathrm{s}$, according to the total distribution system flow $Q_{s y s}=0,394 \mathrm{~m}^{3} / \mathrm{s}$.

Working flow of the pump determine from the ratio:

$$
H_{p}=H_{g}+h_{\text {labs }}+h_{\text {lflow }}, \mathrm{m}
$$

where: $H_{g}$ - geometric flow - difference between the levels of reservoirs with water; $H_{g}=6,0 \mathrm{~m} ; h_{\text {labs }}$ - energy losses in the absorbing pipeline of the pump, $\mathrm{m} ; h_{l \text { flow }}$ energy losses in the flow pipeline, $\mathrm{m}$.

The losses in the absorbing pipeline are rather small, therefore, they was taken equal to $0,5 \mathrm{~m}$. The losses in the flow pipeline are the sum of the losses along the length of pipeline $h_{l}$ and local flow losses $h_{m}$ (which was taken as $30 \%$ from the losses along the length, $\mathrm{m}$ ).

The head losses along the length of the pipeline according to the Weisbach-Darcy ratio:

$$
h_{l}=\lambda \cdot \frac{L}{D_{m p}} \cdot \frac{v^{2}}{2 g}, \mathrm{~m}
$$

where $L-$ the length of the pipeline.

The total head losses along the length for entire distribution system are determined by summing all the losses on all areas of a system, taking into account the length of the area and pipeline diameter of this area. The velocity on the all areas of the system was taken as $v_{e}=2 \mathrm{~m} / \mathrm{s}$, so the total losses along the length for all the distribution system will be about $210 \mathrm{~m}$. Therefore, the losses accounting local resistance will be equal to $273 \mathrm{~m}$. Working flow (eq. 3) $H_{p}=279 \mathrm{~m}$. According to the calculation five pumps CNS 300-300 was accepted.

\section{Summary}

Water distribution - complex task, including various types of researches, from engineering to biological and ecological [25-31]. The hydrological terms of exploitation, hydrological 
properties of the soil researches must be taken into account to prevent the ecologicaleconomic damage [32-36]. The method for distributed water supply of city water reservoir on the example of I-line of Gulf of Cheboksary is developed. Coverage of the basin by two trunk branches with offsets producing the water, taken from the external resource into the basin, into the basin is proposed. In this example, the water is supplied from the Cheboksary reservoir. The all system require the water flow $Q_{s y s}=0,394 \mathrm{~m}^{3} / \mathrm{s}$, if the water volume of the I-line Gulf will be changed four times per year. The system will mainly work at night. The most economical way is to use the native pumps CNS 300-300.

\section{References}

1. K.V. Bespalova, Water supply and sanitary technique 11, 5-7 (2016)

2. J. Withgott, S. Brennan, Environment: The Science Behind the Stories (San Francisco: Benjamin Cummings, 2005)

3. P. O'Sullivan, C.S. Reynolds, The Lakes Handbook: Lake Restoration and Rehabilitation (New Jersey: Wiley, 2005)

4. N. Arefiev, V. Garmanov, V. Bogdanov, Yu. Ryabov, V. Terleev, V. Badenko, Procedia Eng. 117(1) 26-31 (2015)

5. N. Arefiev, V. Terleev, V. Badenko, Procedia Eng. 117 39-44 (2015)

6. L.A. Hansson, The Biology of Lakes and Ponds (Oxford: Oxford University Press, 2005)

7. J. Kalff, Limnology: inland water ecosystems: Upper Saddle River (New Jersey: Prentice Hall, 2002)

8. O. Skvortsova, A. Dashkina, E. Petrovskaia, V. Terleev, A. Nikonorov, V. Badenko, Yu. Volkova, S. Pavlov, MATEC 53, 01014 (2016)

9. O. Degtyareva, G. Degtyarev, I. Togo, V. Terleev, A. Nikonorov, Y. Volkova, Procedia Eng. 165, 1619-1628 (2016)

10. A. Nikonorov, V. Badenko, V. Terleev, I. Togo, Y. Volkova, O. Skvortsova, O. Nikonova, S. Pavlov, W. Mirschel, Procedia Eng. 165, 1731-1740 (2016)

11. M.J. Hammer Sr., M.J. Hammer Jr., Water and Wastewater Technology (New York: Prentice Hall, 2011)

12. M.H. Chaudhry, Applied Hydraulic Transients. 3rd ed. (Luxembourg: Springer, 2013)

13. D. Brkić, W. Lambert, Mathematica Balkanica 26, 285-292 (2012)

14. T.G. Hicks, T.W. Edwards, Pump Application Engineering (New York: McGraw-Hill Book Company, 1971)

15. N.N. Semenova, V.V. Terleev, G.I. Suhoruchenko, E.E. Orlova, N.E. Orlova, Vestnik St. Petersburg University: Mathematics 49, 138-146 (2016)

16. A. Makarov, A. Mihailova, N. Arefiev, S. Pavlov, T. Chashchina, V. Terleev, V. Badenko, Procedia Eng. 117, 225-231 (2015)

17. V.V. Terleev, A.G. Topaj, W. Mirschel, Russ meteorol hydro+ 40, 278-285 (2015)

18. V. Terleev, E. Petrovskaia, N. Sokolova, A. Dashkina, I. Guseva, V. Badenko, Yu. Volkova, O. Skvortsova, O. Nikonova, S. Pavlov, A. Nikonorov, V. Garmanov, W. Mirschel, MATEC web conf. 53, Article no 01013 (2016)

19. N. Arefiev, V. Badenko, A. Nikonorov, V. Terleev, Y. Volkova, Procedia Eng. 117, 20-25 (2015)

20. A. Nikonorov, S. Pavlov, V. Terleev, N. Arefiev, V. Badenko, Y. Volkova, Procedia Eng. 117, 258-263 (2015) 
21. V. Terleev, A. Nikonorov, V. Badenko, I. Guseva, Y. Volkova, O. Skvortsova, S. Pavlov, W. Mirschel, Advances in Civil Engineering 2016, 8176728, 1-7 (2016)

22. V. Terleev, E. Petrovskaia, A. Nikonorov, V. Badenko, Y. Volkova, S. Pavlov, N. Semenova, K. Moiseev, A. Topaj, W. Mirschel, MATEC web conf. 73, Article number 03001 (2016)

23. R.A. Poluektov, V.V. Terleev, Russ meteorol hydro+ 11, $70-75$ (2002)

24. R.A. Poluektov, I.V. Oparina, V.V. Terleev, Russ meteorol hydro+ 11, 61-67 (2003)

25. R.A. Poluektov, S.M. Fintushal, I.V. Oparina, D.V. Shatskikh, V.V. Terleev, E.T. Zakharova, Arch. Acker- Pfl. Boden. 48, 609-635 (2002)

26. R.A. Poluektov, V.V. Terleev, K.Ch. Kersebaum, J.-M. Hecker, W. Mirschel, M. Wegehenkel (Eds), Leibniz Centre of Agricultural Landscape Research (ZALF) in Müncheberg/Germany, 75$89,(2007)$

27. V. Badenko, V. Terleev, A. Topaj, AMM 635-637, 1688-1691 (2014)

28. S. Medvedev, A. Topaj, V. Badenko, V. Terleev, IFIP AICT, 448, 252-261 (2015)

29. V. Badenko, V. Terleev, N. Arefiev, J. Volkova, O. Nikonova. Proceedings of the AASRI International Conference on Industrial Electronics and Applications (IEA 2015). Book Series: AER-Advances in Engineering Research. 2, $452-455$ (2015)

30. R.A. Poluektov, V.V. Terleev, Russ meteorol hydro+ 12, 73-77 (2005)

31. V.V. Terleev, W. Mirschel, U. Schindler, K.-O. Wenkel, INT AGROPHYS. 24, 381-387 (2010)

32. V. Terleev, A. Nikonorov, I. Togo, Y. Volkova, V. Garmanov, D. Shishov, V. Pavlova, N. Semenova, W. Mirschel, Procedia Eng. 165, 1776-1783 (2016)

33. A. Nikonorov, V. Terleev, S. Pavlov, I. Togo, Y. Volkova, T. Makarova, V. Garmanov, D. Shishov, W. Mirschel, Procedia Eng. 165, 1741-1747 (2016)

34. V. Chechevichkin, N. Vatin, AMM 641-642, 409-415 (2014)

35. N. Arefiev. M. Mikhalev, D. Zotov, K. Zotov, N. Vatin, O. Nikonova, O. Skvortsova, S. Pavlov, T. Chashina, T. Kuchurina, V. Terleev, V. Badenko, Y. Volkova, V. Salikov, K. Strelets, M. Petrochenko, A. Rechinsky, Procedia Eng. 117, 32-38 (2015)

36. V. Badenko, N. Badenko, A. Nikonorov, D. Molodtsov, V. Terleev, J. Lednova, V. Maslikov, MATEC web conf. 73, 03003 (2016) 